\title{
Modifying the implementation of group guidance service for improving the quality of guidance and counseling services to school students
}

\author{
Neviyarni Neviyarni*) \\ Universitas Negeri Padang \\ *)Corresponding author, ఏe-mail: neviyarni@konselor.org
}

\begin{abstract}
The aim of this research was to analyze and interprete previews studies on the modification of group guidance service implementation, using a qualitative approach that involves case study's strategies. The findings showed that the average score results of implementing group guidance with modification has better score than without guidance. The suggestions recommended for developing discipline learning include the adoption of bibliotherapy in enhacing self-concept. Meanwhile, other modifications were conducted through Role Playing to improve self-adaptation, the study of the Holy Al-Qur'an verses for motivation, Audio Visual Media for self concept, Assertive Training for interpersonal communication, REBT to eliminate fear, Modeling to improve Self Efficacy, and Reality Counseling was performed to develop self-adaptation. In addition, it is hoped that Guidance and Counseling teachers/Counselors recuperate the quality of service with the implementation of group guidance service through several modifications.
\end{abstract}

Keywords: Counseling modification, guidance and counseling service, group guidance

How to Cite: Neviyarni N. (2019). Modifying the implementation of group guidance service for improving the quality of guidance and counseling services to school students. Couns-Edu: International Journal of Counseling and Education, 4(2): pp. 78-87. DOI: https://doi.org/10.23916/0020190421530

\section{Introduction}

There is a need for services that help solve a variety of students' problems in the current era, which is attainable through the modification of guidance and counseling services. This practice is necessary to improve the skills required by the counselor, hence the study is inspired by the desire to reveal several findings that have previously been covered by previews of studies by college students. The results of instrument implementation through observation, interview, teacher's subject report and class, as well as documentation study, instigate the need for guidance and counseling service, which plays an important role in the development process. This is also related with the function of understanding, placing and delivering, development and problem solving in all aspects, utilizing group guidance.

Nursihan (2003:31) reported group guidance as a form of service for individual students conducted in a group situation, while Prayitno (2012:149) reported on its propensity to lead dynamical groups towards discussions on several benefitial aspects that enhance the progress of members. This implementation is expected to prevent and effectively solve potential problems, emphasising on activation and dynamization, while the role of a group leader is important in controlling activities. In addition, numerous studies have been conducted in post graduate programs in relation with the modifications needed for completing studies on the implementation of group guidance service, Guidance and Counseling 
program, Educational Program, and UNP. These further explained the advantages and subjective preference of execution with modification, as against without.

Group guidance service with modification immerses several techniques, including role playing, bibliography, audio visual, and suggestion. With reference to results on previews studies, the nature of techniques adopted served as a source of variation in effectiveness of modifications towards solving individual problems. Group guidance service helps school students to develop a personality, social relation ability, learning activity, job/position and decision making, and also the conduction of a particular activity through dynamical groups. This is practiced where either the service is preferred for school or its implementation is benefitial, on the basis that once service covers several school students.

There are sets of materials that needs to be conveyed, hence the need for a modification in the implementation service, which is attainable through the limitation of (1) time from teacher of guidance and counseling/counselor during effective hours, (2) existential of counselor rather than school students (at a ratio of 1 counsellor/teacher of guidance and counseling: 150 students), and (3) the demand developing quality services. Furthermore, advancements in each of these areas is necessary for improving the quality of guidance and counseling service, while several considerations and arguments contribute towards supporting the importance of this research.

\section{Method}

This research was conducted through a qualitative approach, using case study, and a collection of previous findings obtained from post graduate students. These served as a basis for deep investigation needed to ascertain the several modifications performed, how they occurred and why, nature of the results, degree of effectiveness, and possibilities of futuristic implementation. Furthermore, modifications in implementing group guidance service were previously conducted on the data obtained, which was followed by analysis using the following steps that evaluate their results description, through a particular modification, including: (1) common activity, (2) specific activity, (3) concluded events /phenomenon, (4) dynamical group present, and (5) results of the group guidance event. Therefore, the opinion on the situation was explained, and the data cited in the form of document reports, with descriptions written in details, concerning attitude/behavior amongst group members. This was initiated with the process that points out the perception of an outcome, as well as an enriched illustration with other related theories, which was followed by the conduction of triangulation with lectures on group guidance subject, and thesis guidance, based on a particular modification. During the activities, the phenomenon from an interlinked group members' perspective were comprehended and the data were related with the context interpreted, followed by the collection, development, interpretation, classification, grouping, deep analysis, drawing conclusion, and establishing theories, based on the evidences available.

\section{Results and Discussions}

\section{Results}

The current research discusses nine results of previews studies, which include: Misda Fitri (2015) used 5 commons steps to conduct a study on group guidance, which include building, changing, activity, conclusion and finishing. Furthermore, the average pretest score for the experimental group was 80.4, which increased to 115.5 after the treatment, alongside suggestions. Meanwhile, the control group had a value of 80.3 , which became 92.2 after the provision of group guidance service without suggestion within a few meeting. Despite the shortcomings, the control group was observed to have developed in discipline, which was lesser than the experiment. This practice was, therefore, assumed to confer a better influence on the development of discipline amongst school students.

Erdawati, (2015) conducted a similar study using 5 common steps, encompassing building, changing, activity, conclusion and finishing. The results showed the development in the aspect of selfconcept amongst those provided with group guidance, using bibliotherapy as a modification, which appreciated from an average pretest score of 86.88 to 163.44 . In addition, the control group had a value of 86.11 , which further increased to 119.88 . Based on analysis, the development of personal concepts through the use of bibliotherapy is seen to be relatively better. 
Yogi Damai Syaputra, (2016) conducted group guidance through role playing modification technique, adopting the 5 related steps. The results revealed an average score of personal adaptation from control group students (pretest) of 86.6, which increased to 116.9 (posttest), while the value obtained for the experiment group was 85.9 and 135.4 for pretest and posttest, respectively. This indicates an elevation in the ability for personal adaptation amongst participating members, where role playing technique lead to strong feelings about the problems faced currently.

Dyla Fajhriani. N, (2016) conducted group guidance using the verse holy Qur'an in the five related steps, through the modification of topics discussed, associated with the aim of developing learning motivation. Furthermore, group members were provided with the opportunity to explore holy Qur'an verses based on related topics, and the results show an average pretest score of 104.38 for the experiment group, while the control was 105.75. Conversely, the posttest values were better at 144.25, and 199.13, respectively, with the exhibition of similarities in their progress, although the experimental group was relatively better. This practice was, therefore, concluded to be highly effective in the process of developing learning motivations.

Fery Anggara, (2016) conducted a study on group guidance using the steps of building, changing, activity, conclusion and finishing, with the nature of the leader as the modification parameter. This involved the invitation of 3 figure models (participant modeling), ordered to assist in topic discussions, speak out on what is thought, and also perceived in wider situations and in related conditions. The study by Fery Anggara runs through a single experiment group, and the result shows an increase in the score of self-efficacy amongst school students at 31.66. Meanwhile, the value for posttest on self-efficacy further developed, characterized by an elevation in the level of effectiveness while facing examinations. In addition, the pretest score was 126.00, which increased to 157.66 after the treatment (modeling), indicating a rise in self-efficacy after the reception of group guidance services through modification modelling.

Hayu Stevani, (2016) reported on the performance of group guidance in four steps, which include building, changing, followed by activity, and finishing, which specifically served as the modification. In addition to the topic discussion, 6 sections of its activities related to REBT theory were conducted, encompassing the ABCD model (Avent, Belief, Consequence, dispute, Effective). The finishing step was characterized by the provision of group members with related homework assignments, where the results showed a decline in the scores for anxiety in the experimental group after guidance treatment alongside Rational Emotive Behavior Therapy. This practice was compensatory, with an average value of 136.1, subsequently placed in the middle category, while the posttest value of 111.5 is classified as low, further indicating a reduction in the anxiety to speak in front of a class.

Siti Muyana, (2016) performed a study on group guidance through four steps, including building, changing, activity, and finishing, where the modification parameter of audio visual media was used to enhance the self-concept of school students. Furthermore, the group leaders played a video that correlates with the discussed topic in the form of an audio visual representation.

The pretest average score of the control group in terms of self-concept was 100.44, which was classified in the less category, encompassing participants that enrolled for treatment through group guidance only. Furthermore, the posttest score obtained was 113.56, which was preferred to the previous value, and classified in the middle category. Meanwhile, the experiment group was 100.89 (less category), and following the enrollment for treatment with audio visual media modification, the posttest score became 124.78 (good category). The result further showed the existence of differences in self-concepts between enrolled group members with audio visual media and others.

Kiki Mariah, (2016) conducted a study on group guidance through five steps, encompassing building, changing, activity, conclusion, and finishing, and the modification adopted during its implementation was the reality counseling approach. The result showed an improvement in the score for self-adaptation of 28.58 , based on the pretest and posttest values of 138.25 and 166.83 (well category), respectively. Meanwhile, the score after treatment of self-adaptation was significant, and more effectively enhanced by the school environment, leading to the possible conclusion that practicing group guidance service through counseling reality approach is more effective in the development of self-adaptation. 
Kristinus Sembiring, (2016) studied group guidance with four steps, including building, changing, activity, and finishing, applying the modification tool of Assertiveness Training technique through role playing. In the control group, the average pretest score was 169.0 (very less category), which increased to 189.3 (less category), while the value from the experiment group was 172.4 (very less category), which increased to 238.8 (high category), known to subsequently improve interpersonal communication ability. This particularly caused an increase in comparison with the control group, indicating the propensity of a greater impact towards the promotion of students' interpersonal ability.

\section{Summary of Results}

There are previous presentations on the explanations of the results for each study modification. However, the ease of checking the quality of guidance and counseling services developed through group guidance modifications required the summary presentation of the comparison between pretest and posttest control and experiment group as seen below:

Table 1. Comparison between Pretest and Posttest with the use of Non Equivalent Control Group Planning

\begin{tabular}{|c|c|c|c|c|c|}
\hline \multirow[t]{2}{*}{ No } & \multirow[t]{2}{*}{ Modification } & \multicolumn{2}{|c|}{ Control Group } & \multicolumn{2}{|c|}{ Experiment Group } \\
\hline & & Pretest & Postest & Pretest & postest \\
\hline 1. & $\begin{array}{l}\text { Power in developing learning } \\
\text { discipline }\end{array}$ & 80,3 & 92,2 & 80,4 & 115,5 \\
\hline 2. & $\begin{array}{l}\text { Bibliotherapy in developing self- } \\
\text { concept }\end{array}$ & 86,11 & 119,88 & 86,88 & 163,44 \\
\hline 3. & $\begin{array}{l}\text { Role Playing in developing self- } \\
\text { adaptation }\end{array}$ & 86,6 & 116,9 & 85,9 & 135,4 \\
\hline 4. & $\begin{array}{l}\text { Verse of Holy Qur'an in developing } \\
\text { learning motivation }\end{array}$ & 105,75 & 119,13 & 104,38 & 144,25 \\
\hline 5. & $\begin{array}{l}\text { Audio Visual Media in developing } \\
\text { self-concept }\end{array}$ & 100,44 & 113,56 & 100,89 & 124,78 \\
\hline 6. & $\begin{array}{l}\text { Assertive Training in developing } \\
\text { interpersonal communication }\end{array}$ & 169,0 & 189,3 & 172,4 & 238,8 \\
\hline
\end{tabular}

As illustrated in table 1, the development of results from the control and experiment group involved the adoption of group guidance, although the level of significance was revealed through the use of several particular modifications. This is characterized by the higher effectiveness in developing several abilities.

Table 2. Comparison between Pretest and Posttest with the use of One Group Pretest-Posttest Design planning

\begin{tabular}{lllc}
\hline No & Modification & \multicolumn{2}{c}{$\begin{array}{c}\text { Experiment Group } \\
\text { Pretest }\end{array}$} \\
& & 136.1 & 111.5 \\
$\mathbf{1}$ & REBT to solve anxiety & 126.00 & 157.7 \\
$\mathbf{2}$ & Modeling to develop self-efficacy & 138.25 & 166.8 \\
$\mathbf{3}$ & Counseling Reality to enhace self-adaptation & 13.7 \\
\hline
\end{tabular}

Table 2 shows information that indicates the effectiveness of group guidance through the use of several specific modifications in developing a variety of abilities, including the elimination of anxiety, without the immersion of control group.

\section{Discussion \\ Group Guidance with the Use of Modification Suggestion}

The study by Fitri, (2015) titled "the Effectiveness of Group Guidance Service in Developing Learning Discipline for School Students with the Use of Modification Suggestion" revealed the comparably greater achievement in learning discipline at the experiment group after an enrollment for the guidance service. This was in line with the findings of Fijriani (2012) which conducted a study termed "Effectiveness of Implementing Suggestion in Group Guidance Service to Develop Self Esteem for School 
Students". The result demonstrated the effectiveness of executing the adoption of suggestion while performing group guidance services through the development of student's self esteem, and also known as an important research benefit, obtained through the conveyance of words and motivation. Furthermore, this practice stimulates other aspects intended for development, especially those in line with discipline.

\section{Group Guidance with the Use of Modification Bibliotherapy}

Numerous studies have shown the capacity for group guidance modified with bibliotherapy to effectively develop student self-concept. Erdawati (2015) on the study termed "Effectiveness of Group Guidance Service with the Use of Modification Bibliotherapy to develop self-concept", reported on the improved average posttest score amongst enrolled students over the control group. This was also in line with the study by Solikin (2015:154), which affiliates the reading activity of bibliotherapy with student age, inside therapy, and therapy, followed by a discussion related to real problems acquired in the environment. Hence, an enhanced effectiveness in the development of self-concept is confirmed.

\section{Group Guidance with the Use of Role Playing}

The result of a study by Syaputra (2016) in the report titled "Effectiveness of Group Guidance Service with the Use of Role Playing as a modification Technique in the Development of Self-Adaptation amongst School Students" showed an enhancement in school students' ability to adapt in the environment. This was a continual process, characterized by the need for self-adaptation, hence students were invited to address personal interactions and communications, provide opinions and ideas, and also think through the process of role playing. Therefore, they were observed to have successfully controlled and managed personal emotions and face frustrations, and also adopt objective and realistic applications, collectively identified as characteristics of positive self-adaptation.

This finding is in line with the opinion of Syah (2010:193), which demonstrated role playing as an effort to solve problems, especially with regards to social live, including self - adaptation on an action. Flora (2014:37) reported on the aspect of role playing, which hopefully affiliates students with a case, characterized by the development of thought processes and desires, despite the provision of preferred achievements on an interpersonal level. This was related to the study outcomes demonstrating the contribution of group guidance and the use of role playing technique for eliminating the act of bullying in the academic years 2012/2013.

Results of the study by Fatimah (2015:28) designed a modification that required the use of role playing technique, and the results proved an enhanced effectiveness of self-efficacy. Others, including the differences in gains scores scale before and after treatment, indicate the observation of significant development, and after the participants enrollment the treatment category demonstrated better values. Meanwhile, counselors possibly used this model as a pathway for services, subsequently assisting the Junior High School student to obtain self-efficacy.

\section{Group Guidance with the Use of Modeling Modification}

A study conducted by Anggara (2016) using 1 experiment group showed an increase in student score for self-efficacy, which effectively developed from the pretest value in the aspect of facing examination, especially for those that enrolled to use the modeling modification. A study by Astuti (2015) titled "the implementation of group guidance using a modeling technique in the development of autonomous learning for students" showed a positive ability. In summary, the utility of group guidance techniques combined with modeling modification was observed to more effectively ensure an upgrade in self-efficacy and autonomy.

\section{Group Guidance with the Use of Holy Qur'an verses}

Results from the study by Fajhriani N, (2016), titled "the Effectiveness of Group Guidance Service with the use of Verse of Holy Qur'an to develop learning Motivation of School Students," showed the development of learning motivation in both experiment and control group after treatment, which was better expressed in the experimental group. Furthermore, this approach was concluded to be effective in the development of learning motivations.

This finding is supported by the study of Gudnanto, dkk (2013:18), where the model of islamic guidance and counseling used to develop self-concept was designed on the basis of Islamic concept in the aspect of Al-Qur'an and Circumcision. Gudnanto, dkk (2013:24) argued about the recommendation of religious group guidance model, and its differentiation from others, which is due to the assumption that 
Al-Qur'an is God's word transferred to prophet Muhammad SAW and written in papers. This was performed narratively from one person to another over the generations, and also by those that read its verse during worship. Furthermore, the existence enables each Muslim to reach a perfection of live in the world and eternity, and also serves as a guide during decision making, in order to be distinct from other creatures and obtain the blessings of Allah SWT. Moreover, Hadits consists of several words, attitudes, determinations and agreements of the Prophet, which has turned into laws in the Islamic religion, while Stapa, Yusuf, and Shaharudin (2012:14) argued about the potential for "Al-Qur'an to provide knowledge, achievement, and development through God's permission. Hence, group guidance using verses of AlQuran was an effective approach in the development of learning motivation.

\section{Group Guidance with the Use of REBT (Rational Emotive Behavior Therapy) Modification}

The results of a study from (2016) about "the Effectiveness of Group Guidance Service with the Use of Rational Emotive Behavior Therapy Modification Approach to Solve Anxiety of College Student" showed a decrease in the anxiety score of the experiment group after receiving the treatment of group guidance service, utilizing the Rational Emotive Behavior Therapy approach. Moreover, the result of a study by Suhendri, dkk, (2012) about "the Effectiveness of Rational-Emotive Group Counseling to Help School students Eliminate Their Anxiety in Facing Examination" demonstrated the effectiveness of this approach. Therefore, the basic concept indicates that humans exist with the potential of either to think rationally and be honest, or irrationally and bad. Also, they tend to possess the desire of self-maintenance, alongside thinking, speaking, loving, the creation of interactions with others, growth and personal actualization, Corey (2009:238). Corey in Ellis (2006:463) further concluded that humans speak, evaluate, and force themselves.

Sugiharto (2005:17) reported on the inspiration of wrong attitude perspective approach by means of irrational thinking during rational emotive counseling. Hence, a single person is unable to think sensibly, resulting from the inability to reason clearly about current and future times, as well as reality and imagination. This leads to a dependence on what others think, which is a tendency possessed by parent and the society, subsequently transferred through several media. The aim of counseling, therefore, is to repair the attitude, perception, the thought process, belief and also improve a clients' irrational and nonlogic views into rational and logical forms, in order to ensure personal enhancement, and improve selfactualization through positive cognitive and affective attitude. Moreover, destructive emotional problems are also eliminated, encompassing the sense of anxiety, guilty, sinfulness, worry, hesitance, and anger.

This finding is supported by the study of Yahya \& Mustaffa (2012) entitled "the Application Of Rational Emotive Behaviour Therapy In Addressing The Problems Of Bulliying at School: A Case Study. Malaysia: Fakulti Pendidikan, Universiti Teknologi Malaysia" which revealed the effectiveness of implementing REBT towards the elimination of bullying problems in schools. Furthermore, a study by Alabi dan Lami (2015), titled "Efficacy of Client-Centred (CCT) and Rational Emotive Behavior Therapies (REBT) in Reducing Bullying Behaviour Amongst School Adolescents in Ilorin, Nigeria", proved the applicability of CCT and REBT counselling approach. In summary, it is concluded that group guidance through REBT modification is an effective technique in the compensation and provision of solutions to the problem of anxiety amongst school students.

\section{Group Guidance with the Use of Audio Visual Media Modification}

A study by Muyana, (2016) revealed the existence of differences in self-concept amongst members in each group guidance service, with or without audio visual media. The average pretest score in the control and experiment group were less, and collectively increased, which was better in the experiment group.

There are numerous strategies in guidance and counseling that are applicable in helping school students solve personal problems. For example, the use of narcotics is possibly attenuated through an understanding of its dangers, using video media during group guidance, followed by discussion sessions. Rahayu (2013:129) selected this technique as a result of the effectiveness in developing a student's comprehension ability, due to the enhanced ease of understanding. Rahayu (2013:134) claimed that utilizing video media enables student's to appreciate the dangerous of narcotics at grade VIII-D of the State of the Junior High School 2 Ngoro.

The study by Mudjiono and Fadjri (2016:14) demonstrated the positive effect of group guidance using audio visual media, which emphasizes on the important role of interpersonal relations development 
within the society. This was supported by the study of Ni Wyn Candriasih, dkk, (2013), which ascertained the impact of this technique in the process of enhancing student empathy. Hence, group guidance with the use of audio visual modification was identified as an effective means to develop self-concept.

\section{Group Guidance with the Use of Counseling Reality Modification}

According to the study by Mariah (2016), entitled "the Effectiveness of Group Guidance Service with the Use of Counseling Reality Approach in Developing Self-Adaptation of School Students in School Environment" the average posttest scores of self-adaptation increased from the pretest. This is in line with the study by Rusdiantie H, and Nursalim M, (2014) entitled "the Implementation of Group Counseling Reality in the Development of Discipline amongst students at VIII-F grade in the State of Junior High School 1 Balongbendo, known to reveal discipline.

This was also supported by Guridham (in Mustaffa and Ilias, 2013), which explained the success of a single man in adapting to instances where feelings ought to be managed, characterized by emotional intelligence while establishing interactions with others. Furthermore, stress and anxiety are known to be natural indicators that ensue in new places, leading to a personalized experience for each individual, as a single man is better able to cope with the proper management of stress and anxiety.

\section{Group Guidance with the Use of Assertive Training Modification}

Kristinus Sembiring (2016) in a study, titled "The Implementation of Assertiveness Training through Role Playing Method in Group Guidance" expressed the effectiveness of developing interpersonal communication ability amongst school students. The results of a research by Turina, dkk, (2016), "Implementation of Assertive Training Technique in Developing Self-Efficacy on Grade VII Students of the State of Junior High School 29 Bandar Lampung" proved the capacity for implementing assertive training, which enables trained skill to provide opinions, display confidence during presentations in public places, demonstrate more effective communication skills in social live, good communication, and others. Bishop (1999:76) reported on the affiliation of assertiveness with self-efficacy, which is attained alongside the ability to provide pricing, arguments, and respect others.

Turina dkk, (2016) associated the use of assertive training with some significant findings. For example, the created pathway for teachers of Guidance and Counseling to develop the personal aspects of students, based on the ability to serve as a personal confidant and the characteristics to foster a social environment. This is supported by the study of Thilbault and Kelley (in Ahmadi, 2007:95), which argued about peoples' perception on the creation of groups or communities, as well as the act of affiliating being happy participating with the pleasure received, and harm or cost paid. Hence, the occurrence of a sense of happiness amongst school students is known to foster the ease of mixing with one another, subsequently providing the opportunity to properly observe and understand each activity properly. Hence, it is important to maintain an assertive training atmosphere to enhance the felling of pleasure for all students, in order to ensure the conduction of significant activities. In summary, the application of guidance with the use of assertive training through role playing technique was identified as an effective method for the development of interpersonal communication competence.

\section{Conducting Triangulation between Lectures on Group Guidance Subject, and Thesis Advisor of College Students in the Implementation of Group Guidance Activities}

A discussion was conducted with lectures on group guidance subject and thesis advisors in Focus Group Discussion (FGD) during a Guidance and Counseling Program, in relation with the study gains of students intended for this evaluation. The results obtained from participants showed various additions and suggestions as shown below: 1) Determine the validity of results by checking the evidences of the studies, including videos, planning the implementation of services, programs, materials/topics, and reports.; 2) Identify the common and specific steps used in relation with a modification; 3) Implement a specific group guidance service, which is needed to explain special information on modifications at the initial stage.

According to the results of the present study, focus group discussion members in the aspect of guidance demonstrated an enhanced effectiveness in the use of a particular technique/strategy for developing the intended characteristic to be performed by Guidance and Counseling teachers. This includes learning discipline, achievement, self-concept, motivation, self-efficacy, and interpersonal communication, hence it is important to determine the implementation, using a specific method. In addition, the present study analyzed the results obtained by college students and discussed in journals, which is further elaborated in the discussion chapter of this report, to strengthen the research outcome. 
Interpreting the Data related to Its Contexts Occurred in the Implementation Group Guidance Activity with the Use of Particular Modification.

Based on table 1 and 2 mentioned above, a recapitulation of studies conducted by post graduate students was presented from pretest to posttest, and the differences between control and experiment groups were also considered. In addition, the gains were expressed as the differences between the recorded scores, where the experiment group involved the use of better modifications, technique/strategy and approach.

During the implementation activity, group guidance activity with modifications made students more active, and high spirited, further promoting the possession of high self-esteem, through the suggestions of Guidance and Counseling teachers, known to serve as group leaders. Therefore, school students obtained new understanding and demonstrated a better positive self-concept, through the use of bibliotherapy modification, as well as learning motivation with the use of Al- Qur'an verses that affect the heart and mind. These students had better self-adaptation, characterized by high spirit, with the tendency to follow group guidance using audio visual media, following the implementation of reality counseling by the teachers. Furthermore, students were observed to be more assertive in establishing communications with others, as those in colleges tend to exhibit greater confidence through role playing in group guidance, as observed in Picture 1.

Picture 1. Modifications of Group Guidance

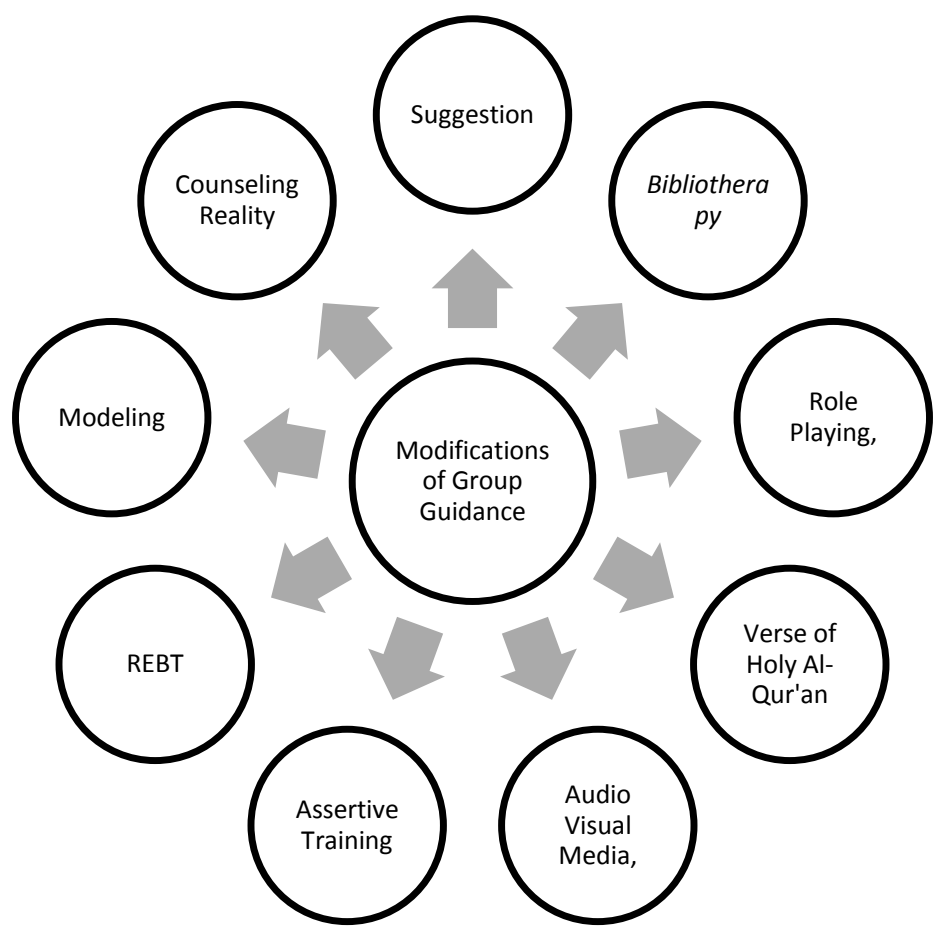

\section{Conclusions}

Based on the results and discussion, it is concluded that conducting Group Guidance was effective for students, using appropriate modification strategy/technique related with the variables to be developed. These modifications involve the adoption of a particular approach, which includes conferring suggestions, bibliotherapy, counseling reality and modeling, the verse of Al-Qur'an, REBT, role playing, audio visual media, and assertive training. Furthermore, the study suggests that teachers of Guidance and Counseling conduct group guidance through modifications that are related with the goal, in order to enhance effectiveness. Also it is recommended that group leaders are more creative in conducting proper guidance activities, using the several modifications available. 


\section{References}

Alabi, Y. L. dan Lami, M. M. (2015). Efficacy of Client-Centred and Rational Emotive Behavior Therapies in Reducing Bullying Behaviour among in School Adolescents in Ilorin, Nigeria. International Journal of Instruction, (Online), Vol. $\quad 8, \quad$ No. 1 (http://files.eric.ed.gov/fulltext/EJ1085293.pdf, diakses pada tanggal 25 Desember 2016).

Anggara, F. (2016). "Efektivitas Layanan Bimbingan Kelompok dengan Modeling dalam Meningkatkan Efikasi Diri Peserta didik dalam Menghadapi Ujian". Tesis. BK FIP UNP

Corey, G. (2010). Teori dan Praktek: Konseling dan psikoterapi. Terjemahan oleh E. Koeswara. Bandung: Rafika Aditama.

Chairani, N. (2015). "Potensi Bibliotherapy dalam mengurangi kecemasan akibat hospitallisasi pada anak usia sekolah". Jurnal. ISSN 2338-4700

Ellis, Albert dan Bernard, Michael E. (2006). Rational Emotive Behavioral Approaches to Childhood Disorders : Theory, Practice and Research. USA : Springer Science+Business Media, Inc.

Erdawati. (2015). "Efektivitas Layanan Bimbingan Kelompok dengan Menggunakan Bibliotherapy untuk Meningkatkan Konsep Diri”. Tesis. BK FIP UNP.

Fajhriani, D. (2016). "Efektivitas Layanan Bimbingan Kelompok dengan Menggunakan Ayat-ayat Alquran untuk Meningkatkan Motivasi Belajar Peserta didik di MTs. Alfurqan Padang”. Tesis. BK FIP UNP

Fatimah, D. (2015). "Pengembangan Model Bimbingan Kelompok dengan Teknik Role Playing untuk Mengembangkan Kepercayaan Diri Peserta didik”. Jurnal. Jurnal Bimbingan Konseling 4 (1). Prodi Bimbingan dan Konseling, Program Pascasarjana, Universitas Negeri Semarang, Indonesia

Fijriani.(2012). "Efektivitas Penerapan Sugesti pada Layanan Bimbingan Kelompok dalam Meningkatkan Self Esteem Peserta didik (Studi Eksperimen di Sekolah Menegah Atas Al-Kautsar Bandar Lampung)".Jurnal. BK FIP UNP

Fitri, M. (2015). "Efektivitas Layanan Bimbingan Kelompok dalam Meningkatkan Disiplin Belajar Peserta didik dengan Sugesti". Tesis. BK FIP UNP.

Flora, R. (2014). "Mengurangi Perilaku Bullying Kelas X-4 Melalui Pemberian Layanan Bimbingan Kelompok Teknik Role Playing di SMA Negeri 12 Medan Tahun Ajaran 2012/2013. Jurnal. Saintech Vol. 06 No. 02-Juni 2014. ISSN No. 206-9681

Gudnanto. (2013). "Model Bimbingan dan Konseling Islami untuk Meningkatkan Konsep Diri Peserta didik". Jurnal Bimbingan Konseling 2 (1) (2013). Prodi Bimbingan dan Konseling, Program Pascasarjana, Universitas Negeri Semarang, Indonesia.

Mariah, K. (2016). " Efektivitas Layanan Bimbingan Kelompok dengan Pendekatan Konseling Realitas dalam Mengembangkan Penyesuaian Diri Peserta didik di lingkungan Sekolah pada Peserta didik Kelas X SMAN 1 Sungai Tarab".Tesis. BK FIP UNP.

Mustaffa, C.S., dan Ilias, M. (2013). Relationship between Students Adjustment Factors and Cross Cultural Adjustment: A Survey at the Northern University of Malaysia. Journal of Intercultural Communication Studies, (Online), Vol. XXII, No. 1, 279-300, (diakses 3 Mei 2017).

Muyana, S.(2016). "Efektivitas Pelaksanaan Layanan Bimbingan Kelompok dengan Menggunakan Media Audio Visual untuk Meningkatkan Konsep Diri Peserta didik di SMK Negeri 9 Padang”. Tesis. BK FIP UNP.

Ni Wyn Candriasih, Gd Sedanayasa, Tjok Rai Partadjaja. (2013) "Penerapan Bimbingan Sosial Berbantuan Media Audio Visual Untuk Mengembangkan Empati Peserta didik Kelas VIIID3 SMP Negeri 2 Sawan. Jurnal. Bimbingan Konseling, Singaraja: Universitas Pendidikan Indonesia.

Nurihsan, Achmad Juntika. (2003). Dasar-dasar Bimbingan dan Konseling. Bandung: Mutiara.

Prayitno. (2012). Seri Layanan Konseling. Padang: FIP UNP.

Rusdiantie, H dan Nursalim, M. (2014). "Penerapan Konseling Kelompok Realita untuk Meningkatkan Disiplin Peserta didik Kelas VIII.F SMP Negeri 1 Balongbendo". Jurnal. Volume 5 Nomor 01 , 1-8. BK FIP Universitas Negeri Surabaya.

Sembiring, K (2016). "Penerapan Assertiveness Training melalui Metode Bermain Peran dalam Bimbingan Kelompok untuk Meningkatkan Kemampuan Komunikasi Interpersonal Peserta didik". Tesis. BK FIP UNP 
Solikin, A. (2015). "Bibliotherapy sebagai Sebuah Teknik dalam Layanan Bimbingan dan Konseling". Anterior Jurnal, Volume 14 Nomor 2, Juni 2015, Hal 154 - 161. Program Studi Bimbingan dan Konseling Fakultas Keguruan dan Ilmu Pendidikan Universitas Muhammadiyah Palangkaraya.

Stapa, Zakaria, Yusuf, Norahizah, and Shaharudin, Amdul Fatah. (2012). "Education According to Alquran and Sunnahand Its Role in Strengthening the Civilization of Ummah". Journal Hadhari Special Edition, 7 - 22.

Stevani, H. (2016). "Efektivitas Layanan Bimbingan Kelompok dengan Pendekatan Rational Emotive Behavior Therapy untuk Mengatasi Kecemasan Mahasiswa (Studi Pada Mahasiswa IAIN Imam Bonjol Padang)". Tesis. BK FIP UNP

Suhendri, dkk. (2012). "Efektivitas Konseling Kelompok Rational-Emotif Untuk Membantu Peserta didik Mengatasi Kecemasan Menghadapi Ujian". Jurnal. Prodi Bimbingan Konseling, Program Pascasarjana, Universitas Negeri Semarang, Indonesia

Syah, M. (2010). Psikologi Pendidikan. Bandung: Remaja Rosdakarya

Tohirin. (2013). Bimbingan dan Konseling di Sekolah dan Madrasah (Berbasis Integrasi). Jakarta: Raja Grafindo Persada.

Syaputra, Y.D. (2016). "Efektivitas Layanan Bimbingan Kelompok dengan Menggunakan Teknik Role Playing dalam Meningktakan Penyesuaian Diri Mahasiswa Tahun Pertama Program Studi Bimbingan dan Konseling di STAIN Batusangkar". Tesis. BK FIP UNP.

Turina, dkk. (2016). "Penggunaan Teknik Assertive Training dalam Meningkatkan Rasa Percaya Diri Pada Peserta didik Kelas VII SMP N 29 Bandar Lampung". Jurnal.

Yahya, N \& Mustaffa, M. S. (2012). Application Of Rational Emotive Behaviour Therapy In Addressing The Problems Of Bulliying In The School: A Case Study. Malaysia: Fakulti Pendidikan, Universiti Teknologi Malaysia. Journal of Educational Psychology \& Counseling, (Online) Volume 6 (diakses pada tanggal 25 Desember 2016). 